\title{
ПРАВОВАЯ СИСТЕМА
} ПРЕДПРИЯТИЙ С ИНОСТРАННЫМ КАПИТАЛОМ КНР И ТЕНДЕНЦИИ ЕЕ РАЗВИТИЯ

Аннотация. Точкой опоры правовой системы предприятий с иностранным капиталом в КНР являются «коммерческие организации», ядром системы - Законы "О паевых совместных предприятиях китайского и иностранного капитала", "О предприятиях с иностранным капиталом», "О китайско-иностранных совместно управляемых предприятиях» и др., касающиеся предприятий с иностранным капиталом. Данная правовая система сочетает в себе корпоративное право, антимонопольное законодательство и другое отраслевое законодательство, а также связывает в единое целое всю совокупность правовых систем с целью регулирования доступа к прямым иностранным инвестициям, их обращения, управления и др. С юридической точки зрения, нормы корпоративного права признаются общими нормами, а нормы Закона «О предприятиях с иностранным капиталом» - специальными. Если придерживаться принципа правоприменения, по которому специальные нормы доминируют над общими, то можно разрешить любые правовые споры. КНР использует метод привлечения прямых иностранных инвестиций, кроме привлечения инвестиций на образование новых предприятий. КНР дала возможность иностранным предпринимателям также использовать метод поглощения (слияния) для образования новых предприятий, но такая возможность регулируется антимонопольным законодательством. Кроме этого, КНР методом разделения (унификации) законов предоставила иностранным инвесторам оптимальную льготную политику. В настоящее время проблемы правовой системы предприятий с иностранным капиталом в КНР проявляются в ее громоздкости, дублировании статей законодательства и сложности правовой системы, которая включает в себя как внутренний, так и внешний капитал. В связи с этим КНР начала процесс дальнейшего совершенствования законодательства компаний с иностранным капиталом, куда входит ослабление "высшего национального режима» и «низшего национального режима» иностранных предприятий, возможность упразднения отдельных законов, касающихся предприятий с иностранным капиталом, разработка единого Закона "Об иностранных инвестициях» и создание хорошего инвестиционного климата.

Ключевые слова: Китай, предприятие с иностранным капиталом, закон, паевые совместные предприятия, китайско-иностранные совместно управляемые предприятия, корпоративное право, антимонопольное законодательство, поглощение (слияние) предприятий, национальный режим, тенденции развития.

DOI: 10.7256/1729-5920.2014.1.10337

(C) Ли Ляньци

* Доктор юридических наук, доцент Хэйлунцзянского университета

[rusun2008@gmail.com]

150080, КНР, провиция Хэйлунцзян, г. Харбин, район Нань Ган, ул. Сюе Фу, д. 74.

\footnotetext{
Статья подготовлена в рамках проектов: «Исследование спорных правовых вопросов политики

России в отношении минеральных ресурсов и разработки полезных ископаемых» (11YЈС820058) при поддержке Молодежного фонда гуманитарных и общественных наук Министерства образования, возглавляемого автором данной статьи; 2012 г. "Исследование оценки сферы инвестиционного законодательства в области горнодобывающей промышленности Северо-Восточной Азии и ответных мер Китая в условиях современной обстановки» (12D095); Китайско-российского центра взаимодействующей инновации и гуманитарного сотрудничества в 2012 г. на тему "Исследование ключевых проблем гражданского и коммерческого права на фоне стратегического сотрудничества КНР и РФ» (№ 2012ZD006).
} 
$\mathrm{B}$ КНР самый оживленный рынок иностранных инвестиций в мире. На 1 января 2013 г. уже было освоено 1, 34 трл долл. иностранных инвестиций ${ }^{1}$. За прошедшие 10 лет Китай постепенно занял первое место по привлечению прямых иностранных инвестиций среди развивающихся стран.

1 июля 1979 г. КНР приняла первый правовой акт, касающийся иностранных инвестиций, - Закон «О паевых совместных предприятиях китайского и иностранного капитала КНР». До настоящего времени издано более 200 законодательных и нормативных актов относительно иностранных инвестиций, а соответствующие положения были детализованы до индивидуальных областей применения ${ }^{2}$. Все эти нормативные акты эфффективно защищают права и собственность иностранных инвесторов. В данной статье главным образом исследуется современное положение и проблемы развития предприятий с иностранным капиталом в КНР, а также дается логичное заключение по поводу будущих тенденций развития.

\section{Формирование правовой основы предприятий с иностранным капиталом}

Правовая система предприятий с иностранным капиталом состоит из двух составных частей.

Законодательные и нормативные акты о предприятиях с иностранным капиталом. В широком смысле слова, законодательство o предприятиях с иностранным капиталом включает в себя Законы: «О паевых совместных предприятиях китайского и иностранного капитала» (от 1 июля 1979 г.); «О предприятиях с иностранным капиталом» (от 12 апреля 1986 г.); «О китайско-иностранных совместно управляемых предприятиях» (от 14 апреля 1988 г.); Корпоративное право (от 29 декабря 1993 г.). Оно охватывает соответствующие административно-правовые акты, например «Подробные правила применения закона о предприятиях с иностранным капиталом» (от 28 октября 1990 г.), «Правила исполнения закона о паевых совместных предприятиях

Китайский статистический ежегодник. 2012. Ми нистерство торговли КНР // http://www.mofcom.gov.cn/ $(19 / 5 / 2013)$

Е Линь. Закон о предприятиях с иностранным капиталом в стадии преобразования // Научная газета университета Янчжоу (издание научного гуманитарного общества), 2012. № 3. С. 17-18. китайского и иностранного капитала» (от 20 сентября 1983 г.), «Положения о поглощении (слиянии) иностранными инвесторами внутренних предприятий» (от 8 августа 2006 г.), «Административные меры по регистрации вкладов в акционерный капитал» (от 1 марта 2009 г.), «Методы управления совместным предприятием, созданным в Китае иностранной компанией или фризическим лицом» (от 1 марта 2010 г.), «Правила управления регистрацией иностранных предприятий как постоянного представительства» (от 1 марта 2011 г.), а также многосторонние международные договоры, например «Договор о разрешении инвестиционных споров между гражданами Китая и другого государства», «Договор о создании механизма гарантии многосторонних инвестиций» и др. Эти правовые акты реально демонстрируют, что в КНР уже сформирована правовая система предприятий с иностранным капиталом.

Статья 18 Конституции КНР постановила, что КНР разрешает иностранным предприятиям и другим организациям хозяйственной деятельности или фризическому лицу согласно нормам китайского законодательства осуществлять в Китае инвестиционную деятельность и различные виды экономического сотрудничества с китайскими предприятиями или другими организациями хозяйственной деятельности. Все законные права и интересы таких организаций защищены законодательством КНР. Согласно положениям Закона «О предприятиях с иностранным капиталом» предприятия с иностранным капиталом соответствуют статусу юридического лица, определенному в китайском законодательстве. Статья 4 Закона «О паевых совместных предприятиях китайского и иностранного капитала» четко определила, что форма совместно управляемого предприятия - это общество с ограниченной ответственностью. В Корпоративном праве специально подчеркнуто, что компания (фирма) - это предприятие - юридическое лицо, у которого есть независимое имущество и которое наделено правом собственности. Компания несет ответственность за долги всем своим имуществом (ст. 3). Закон «О предприятиях с иностранным капиталом» установил, что предприятия с совместным капиталом должны иметь фрорму общества с ограниченной ответственностью. Цель Закона - защитить права и интересы инвесторов, а ответственность каждого инвестора ограничивается только суммой собственного вклада и не распространяется на другое личное имущество, поэтому инвесторы не могут 
потерпеть бо́льший убыток. Вследствие этого считается, что нормы законодательства о предприятиях с иностранным капиталом соответствуют правовой системе предприятий свободных рынков западных государств ${ }^{3}$.

Кроме паевого совместного предприятия китайского и иностранного капитала, предприятия с иностранным капиталом могут иметь и другую организационно-правовую форму: китайско-иностранные совместно управляемые предприятия и компании с иностранным капиталом. Компании с иностранным капиталом - это компании, основанные на территории Китая в соответствии китайским законодательством, весь капитал которых является иностранными инвестициями, но не включают в себя дочерние компании (филиалы) иностранных предприятий и других иностранных организаций хозяйственной деятельности, расположенных на территории Китая. Индивидуальные частные предприятия играют роль важного связующего звена в процессе трансформации КНР. Для транснациональных корпораций (ТНК) они являются излюбленной моделью осуществления инвестиционной деятельности, так как могут дать ТНК возможность полного господства. В настоящее время ход развития ТНК приводит к трансформации типов предприятий с иностранным капиталом, основной тенденцией стало образование предприятий со 100\% иностранным капиталом, что, в свою очередь, также является тенденцией развития законодательства предприятий с иностранным капиталом КНР.

Первоначально для привлечения иностранных инвестиций в Китае учреждали совместные предприятия, тем самым надеялись создать систему свободного предпринимательства наподобие западных стран, которая бы привлекала ТНК. В результате этого совместные предприятия получили довольно большую гибкость в развитии. Статья 218 Корпоративного права определила, что общества с ограниченной ответственностью и акционерные общества с ограниченной ответственностью, основанные с помощью иностранных инвестиций, применимы к данному праву; соответствующие законы об иностранных инвестициях устанавливаются в особом порядке и правоприменимы. В правовой системе предприятий с иностранным капиталом КНР Корпоративное право является общим законом, а Закон «О предприятиях с иностранным капи-

\footnotetext{
Ван Баошу. Направления реформы структуры Корпоративного права // Китайское правоведение. 2012 № 1. C. 113-115.
}

талом» - специальным законом. С юридической точки зрения, положения Корпоративного права - это общие положения, а положения Закона «О предприятиях с иностранным капиталом» - особые положения. Если придерживаться принципа правоприменения, по которому специальные нормы доминируют над общими нормами, и одновременно с этим принимать во внимание функциональную роль соответствующих законов низшего ранга (уровнем ниже), касающихся предприятий с иностранным капиталом, в практическом управлении иностранным капиталом, то можно разрешить любые правовые споры. Ввиду этого мы сможем понять переходную модель развития китайской экономики и предприятий с иностранным капиталом. Среди предприятий с иностранным капиталом предприятия со 100\%-м иностранным капиталом стали основной формой предприятий-заводов, создаваемых с помощью иностранных инвестиций.

Разделение (унификация) законов. Цель унификации законов - создать оптимальные и благоприятные условия для иностранных инвесторов. Для привлечения иностранных инвестиций КНР уже разработала и осуществила ряд мероприятий по созданию льготных условий. В настоящее время в правовых системах, созданных КНР для инвесторов, есть различия, так как местные правительства также приняли соответствующие политические курсы для стимулирования иностранных инвесторов ${ }^{4}$, например «Льготная политика по привлечению инвесторов в г. Харбине», «Временные положения по поощрению иностранных инвестиций в г. Цзямусы». КНР приняла к исполнению политический курс низкого налогообложения для предприятий с иностранным капиталом. В отраслях и районах с льготной налоговой политикой, где поощряются инвестиции, предприятия с иностранным капиталом и иностранные физические лица платят следующие налоги:

- подоходный налог с предприятия;

- подоходный налог с физических лиц;

- налог на добавленную стоимость;

- налог с продаж (акциз)

Кроме этого, согласно установкам политического курса, также имеет место полное или частичное освобождение от налогов.

11 декабря 2001 г. КНР вошла во Всемирную торговую организацию (ВТО). Вступление

\footnotetext{
Чэнь Ехун, Чжоу Етин. Размышления на тему ведущей идеологии законодательства по регулированию инвестиционной деятельности в КНР // Право. 2013. № 3. C. $40-43$.
} 
КНР в ВТО стало для иностранных инвесторов стимулом к вхождению на огромный китайский рынок, в особенности это позволило иностранному капиталу попасть в ранее ограниченные или запретные для иностранного капитала области. Для того чтобы соответствовать требованиям ВТО, в законодательство КНР были внесены соответствующие изменения. Поправки в законодательство о предприятиях с иностранным капиталом были готовы еще до $2000 r^{5}$. Китайское правительство издало 30 административно-правовых норм, которые касались таможни, разрешений на экспорт и импорт, защиты торговой деятельности и др. КНР радикально изменила правовую систему предприятий с иностранным капиталом для того, чтобы она отвечала международным стандартам. Например, КНР приняла антидемпинговый закон и антимонопольное законодательство, нормативные акты по регулированию и контролю иностранной валюты, охране коммерческой тайны и др. Для повышения безопасности иностранных инвесторов, охраны прав и законных интересов предприятий, Правительство Китая подписало с рядом стран соглашения о поддержке и защите взаимного инвестирования, а также предотвращения двойного налогообложения. На практике некоторые европейские государства и Китай являются государствами, которые одни из первых заключили соглашения о защите инвестиций.

Иностранные инвесторы во время своей коммерческой деятельности в Китае в первую очередь должны обращать внимание не на законодательные и нормативные акты, касающиеся предприятий с иностранным капиталом, а на то, есть или нет в Китае какого-либо провозглашенного общего курса в отношении промышленности. Важные официальные объявления КНР зачастую могут повлечь за собой последующий законодательный курс правительства. Если в полной мере осознать содержание политического курса такого рода, то в руках будет ключ к успеху в развитии предприятия. Что касается руководящих законодательных актов и политического курса, носящих программный характер, то еще начиная с 1950-х гг. КНР беспрерывно утверждает «Пятилетние планы». С 1953 по 1957 гг. был осуществлен «Первый пятилетний план», краткое название которого «Первая пятилетка». С 2011 по 2015 гг.

Чжан Найгэнь. Обсуждение изменений китайской правовой системы под воздействием правовых положений ВТО // Юрист. 2011. № 1. С. 10. проходит «Двенадцатая пятилетка». Она оказала огромное влияние на инвестиционную деятельность Китая. Среди самых заметных особенностей - это внутриконтинентальное расположение хозяйственной деятельности. Исходная точка для иностранных инвесторов - перемещение с прибрежных территорий на обширные территории внутреннего континента и, согласно установке на расширение внутреннего спроса, более тесное слияние с внутренним рынком континентального Китая. Кроме этого, китайское правительство еще в июне 1995 г. начало издавать «Временные положения по указанию направления иностранных инвестиций» и «Сборник установок для промышленности, основанной на иностранных инвестициях», которые содержат четкие правила по таким моментам, как поощрение, разрешение, ограничение и запрет иностранных инвестиций.

Подводя итог, можно сказать, что китайское законодательство в отношении предприятий с иностранным капиталом в общей сложности прошло четыре этапа: начало, развитие, становление и интернационализация. В это время имело место объединение отдельных законодательных актов и создание двойной правовой системы - внутреннего капитала и иностранного капитала, что привело к громоздкости и запутанности правового регулирования деятельности предприятий с иностранным капиталом. Законодательные и нормативные акты дублировались и вступали в коллизию. Это создавало сложности для инвесторов и шло вразрез с многочисленными принципами ВТО.

Для присоединения к ВТО КНР обязана была исправить законодательные акты, противоречащие Соглашению по торговым аспектам инвестиционных мер (Соглашение TRIMs) и не должна была осуществлять инвестиционные меры, которые противоречат основным правам граждан и повсеместно ликвидируют положения о количественных ограничениях (квотах). Кроме этого, предусматривалось информирование о мерах, которые не соответствуют соглашениям TRIMs. Столкнувшись c такой тенденцией к трансформации, перед первоначальным законодательством трех типов предприятий с участием иностранного капитала встало три вопроса: объединение в единое целое, новое разграничение правовой системы предприятий с иностранным капиталом и стандартизация инвестиционных отношений с помощью внутриэкономического законодательства. Кроме этого, необходимо было улучшить само содержание законода- 
тельства о предприятиях с иностранным капиталом. КНР уже внесла поправки в Законы «О паевых совместных предприятиях китайского и иностранного капитала», «О предприятиях с иностранным капиталом», "О китайско-иностранных совместно управляемых предприятиях» и подробные правила применения законодательства трех типов предприятий с участием иностранного капитала. Но несмотря на то, что все эти поправки были направлены на приведение указанных актов в соответствие с требованиями ВТО, проблемы громоздкости и дублирования законодательства о предприятиях с иностранным капиталом, а также существования двойной системы внутреннего и иностранного капиталов не были решены. Достичь окончательной цели по образованию двух отдельных систем внутреннего капитала и иностранного капитала не удалось.

Законодательство в отношении поглощения (слияния) предприятий Китая иностранными предпринимателями. В последние годы КНР применяла метод привлечения прямых иностранных инвестиций, в основном инвестиции для образования новых предприятий. Постановление о поглощении (слиянии) предприятий, находящихся внутри страны, иностранными инвесторами 2006 г. дало возможность иностранным предпринимателям использовать метод поглощения (слияния) для образования новых предприятий в Китае. Данное Постановление содержит подробные правила в отношении ограничения перечня предприятий, которые могут быть поглощены иностранными инвесторами, пропорций инвестиций, ответственности по долговым обязательствам после поглощения (слияния), положения акционеров (пайщиков), договорной цены поглощения (слияния) и т.д. Кроме этого, оно демонстрирует то, что китайское правительство разрешило иностранным предпринимателям осуществлять инвестиционную деятельность различными методами и на всей территории Китая, включая распространенный в международном сообществе метод поглощения (слияние) для образования новых предприятий. Например, были разрешены: заключение соглашений о слиянии (поглощении); входить на рынок прав собственности предприятий для осуществления слияния; входить на фрондовый рынок для осуществления слияния; такой метод слияния, когда иностранная сторона совместного предприятия передает права акционера и тем самым увеличивает долю акций и др. 30 августа 2007 г. КНР завершила законодательный процесс создания Антимонопольного зако- нодательства (1 августа 2008 г. оно вступило в законную силу). С точки зрения правовой иерархии, Антимонопольное законодательство явно доминирует над Постановлением о поглощении (слиянии) предприятий, находящихся внутри страны, иностранными инвесторами; по этой причине оно обладает более высокой легитимностью. Когда имеют место противозаконные действия, уполномоченные компетентные органы должны провести административное расследование и определить меру пресечения. В китайском Антимонопольном законодательстве нет нечетких статей, которые используются для ограничения неугодных сделок. После внесения поправок оно также разрешило иностранным инвесторам осуществлять поглощение (слияние) 6 .

Если говорить о правовой структуре, касающейся поглощения китайских предприятий иностранными инвесторами, то в будущем за основу будут взяты нормы Антимонопольного законодательства и Постановления о поглощении (слиянии) предприятий, находящихся внутри страны, иностранными инвесторами ${ }^{7}$. Статья 2 данного Постановления определила два метода поглощения (слияния)․․ Первый метод называется «поглощение (слияние) акций», т.е. иностранные инвесторы покупают акции акционеров китайских предприятий без участия иностранного капитала или подписываются на дополнительную эмиссию акций китайского предприятия, тем самым китайская компания становится предприятием с иностранным капиталом; второй метод - «поглощение (слияние) активов», т.е. иностранные инвесторы основывают предприятие с иностранным капиталом, затем с помощью соглашения от имени этого предприятия покупают активы китайского предприятия и пускают их в оборот, или иностранные инвесторы, на основе соглашения, покупают активы китайской фирмы и с помощью этих активов основывают предприятие с иностранным капиталом, затем пускают эти активы в оборот.

Фундаментальными основами контроля транснациональных поглощений и слияний

Сесиль Корс Линделл. Объединение законов КНР вызывает беспокойство. Сделка 28 ноября 2007 г. // http://www.law.com/jsp/law/international/Law ArticleIntl. jsp?id $=900005558744$.

Юй Цзиньсун. Джан Сяонин. Разрешение спора между иностранными инвесторами и принимающим государством, а также его влияния // Китайское правоведение. 2005. № 5. С. 180-183.

8 Е Вэйпин. Значимость создания Антимонопольного законодательства // Китайское правоведение. 2012. № 3. C. 136-138. 
являются нормы о доминирующем положении на рынке и концентрации хозяйствующих субъектов. В ст. 17 Антимонопольного законодательства отмечено, что доминирующее положение на рынке - это положение, когда хозяйствующий субъект на соответствующем рынке обладает возможностью контролировать цены на товары и их количество или другие сделки либо имеет возможность препятствовать или влиять на возможность вхождения на этот рынок других хозяйствующих субъектов. Согласно ст. 19 Антимонопольного законодательства, судить о том, что хозяйствующий субъект обладает доминирующим положением на рынке, можно только в том случае, если:

1) доля рынка одного хозяйствующего субъекта на соответствующем рынке составляет $1 / 2$;

2) общая доля рынка двух хозяйствующих субъектов на соответствующем рынке составляет 2/3; общая доля рынка трех хозяйствующих субъектов на соответствующем рынке - 3/4. Если доля рынка хозяйствующего субъекта менее $1 / 10$, то считается, что такой он не обладает доминирующим положением на рынке.

Положения о концентрации хозяйствующих субъектов закреплены в ст. 27 и 28 Антимонопольного законодательства. Дело о приобретении одной китайской кампании компанией Coca-Cola является классическим примером, касающимся пресечения концентрации хозяйствующих субъектов.

Соглашение компании Coca-Cola о приобретении компании Хуэй Юань (HuiYuan) является первой сделкой, к которой было применено Антимонопольное законодательство. Вскоре после оказания огромной поддержки Олимпийским играм в Пекине компания CосаCola, пользуясь случаем, объявила о покупке китайской компании «Соки Хуэй Юань» за 2,4 млрд. долл. ${ }^{9}$ Компания Coca-Cola является самым большим поставщиком газированных напитков на китайском рынке, а корпорация «Соки Хуэй Юань» - лидером на китайском рынке соков. Приобретение компании «Соки Хуэй Юань» еще больше усилило бы положение компании Coca-Cola на китайском рынке. Доля компании Coca-Cola на китайском рынке напитков составляет 15\%, а после покупки компании «Соки Хуэй Юань» она бы достигла

Пань Чжичэн. Анализ причин отклонения Министерством торговли предложения компании Coca-Cola в покупке компании «Соки Хуэй Юань» // Правоведение. 2009. № 7. С. 82.
20\%. В этом случае ведущее положение компании Coca-Cola на китайском рынке стало бы неоспоримым. Министерство торговли исходя из того, что «в будущем такая ситуация окажет отрицательное влияние на конкуренцию», отказала компании Coca-Cola в такой сделке.

Министерство торговли, основываясь на ст. 27 и 28 Антимонопольного законодательства, приняло на рассмотрение дело, уделив особое внимание следующим моментам: доля рынка и господство на рынке; рыночная концентрация; влияние концентрации на вхождение на рынок и технический прогресс; влияние концентрации на потребителей и других заинтересованных хозяйствующих субъектов; влияние бренда на создание конкуренции на рынке соков и напитков и др. ${ }^{10}$ Министерство торговли определило: концентрация хозяйствующих субъектов, проходящих по этому делу, окажет отрицательное влияние на конкуренцию. После объединения компания Coca-Cola, возможно, воспользуется своим брендом и займет доминирующее положение на рынке напитков; это приведет к тому, что потребители будут вынуждены платить за продукцию более высокую цену, а ее разновидность уменьшится. Вместе с тем такое объединение приведет к притеснению мелких и средних китайских предприятий по производству соков, что создаст отрицательное влияние на конкуренцию китайского рынка соков и напитков. Исходя из этого на основании ст. 28 Антимонопольного законодательства Министерство торговли вынесло решение о запрете такой сделки ${ }^{11}$.

Цель антимонопольной проверки в том, чтобы сохранить честную рыночную конкуренцию, защитить интересы потребителей и общественные интересы. Вплоть до 31 марта 2013 г. Министерство торговли в общей сложности получило 698 ходатайств, касающихся концентрации хозяйствующих субъектов, которым требовалась антимонопольная проверка, из них 627 были приняты, по 579 делам были вынесены решения. Среди дел, по которым вынесли решения, безоговорочной ратификации подвергнуты 562 дела, т.е. 97,1\%, с оговорками ратифицированы 16 дел, запрет на совершение сделки был вынесен по одному делу12.

Если на рынке Китая производство носит региональный характер или направлено

\footnotetext{
10 Е Вэйпин. Указ. соч. С. 136-138.

11 Пань Чжичэн. Указ. соч. С. 82-83.

12 Пресс-конференция Министерства торговли 23 мая 2013 г., http://www. mofcom. gov.cn/ article/ae/ag/ 201305/20130500137422.shtml.
} 
на удовлетворение внутреннего спроса, в отношении монополий и объединенных предприятий существуют определенные правила. Проверка таких предприятий компетентными органами будет иметь строгий характер, а вероятность того, что поглощение (слияние) предприятий затронет Антимонопольное законодательство, будет очень высокой.

Что же касается иностранных инвесторов, то во время осуществления поглощения (слияния) предприятия им необходимо руководствоваться основными и общими нормами Антимонопольного законодательства и Постановления о поглощении (слиянии) предприятий, находящихся внутри страны, иностранными инвесторами. Кроме того, необходимо изучить природу поглощения (слияния) и условия целевого предприятия, затем с учетом особенностей применить другие законодательные акты.

Тенденции развития правовой системы предприятий с иностранным капиталом КНР. Правительство Китая будет осуществлять дальнейшее улучшение законодательства для привлечения иностранных инвестиций и соответствия принципам ВТО. Основные задачи в сфере законодательства, касающегося иностранных инвестиций, следующие:

1) ослабление тенденции предоставления предприятиям с иностранным капиталом «Высшего национального режима» и «Низшего национального режима»

В сорере международных инвестиций такие стандарты, как «Высший национальный режим» и «Низший национальный режим», означают, что в равных или схожих ситуациях положение (права, льготы) иностранных инвесторов выше или ниже положения национальных инвесторов. В настоящее время в связи с изменениями в развитии политики по привлечению иностранных инвестиций в Китай проявилась такая особенность, как постепенное ослабление тенденции предоставления предприятиям с иностранным капиталом «Высшего национального режима» и «Низшего национального режима». Это проявляется в постепенном уменьшении ограничений по допуску иностранных инвестиций; отмене таких требований, как валютный баланс и прибыль от экспорта; постепенном открытии новых сфер для инвестиционной деятельности; информировании общественности о политическом курсе по привлечению иностранных инвестиций путем принятия законодательных и нормативных актов; непрерывном улучшении правовой системы защиты прав на интеллектуальную собственность.
КНР вообще следует отменить политику предоставления предприятиям с иностранным капиталом «Высшего национального режима» и «Низшего национального режима» ${ }^{13}$. Например, нужно ослабить всякие льготные меры и привести в исполнение политику, когда налоговое бремя является справедливым как для китайских, так и для иностранных предпринимателей; упростить порядок образования и утверждения предприятий с иностранным капиталом; еще больше упростить процесс рассмотрения и утверждения инвестиционных проектов; осуществить объединение и упрощение процесса рассмотрения и утверждения внутренних и внешних инвестиций, когда сложатся подходящие условия; внести поправки в регулирование лицензий и квот, а также исправить другие нетарифные барьеры ${ }^{14}$.

Конечно же, национальный режим неполностью ликвидирует ограничения страны-реципиента относительно особого отношения к иностранным инвестициям. КНР это развивающаяся страна, ее экономическая мощь еще недостаточно сильна, и она не может безоговорочно и повсеместно предоставлять национальный режим всему иностранному капиталу, обязана определить надлежащие исключения. Такое положение дел проявляется в том, что Китай поощряет иностранные инвестиции в отсталые секторы промышленности, например в сельское хозяйство, энергетику, коммуникации и транспорт, основные виды сырья, высокие технологии, сферу использования ресурсов, а также рациональное освоение западных районов Китая. Это нашло отражение в Сборнике руководства для промышленности, основанной на иностранных инвестициях, в котором четко были выделены сферы промышленности, открытые для иностранных инвестиций.

Кроме того, «Некоторые политические установки в отношении масштабного освоения западного Китая» (начиная с 2000 г.) являются успешным примером льготной политики привлечения иностранных инвестиций в Китай. Необходимо разграничить законодательство в отношении иностранных инвестиций этих особых экономических зон, что включает в себя особые условия и механизм поощрения. Провинциальное разграничение Китая предоставит еще больше выгоды предприятиям с иностранным капиталом.

\footnotetext{
13 Чэнь Ехун, Чжоу Етин. Указ. соч. С. 40-43.

14 Ван Баошу. Указ. соч. С. 113-115.
} 
Oтдельные акты китайского законодательства в отношении предприятий с иностранным капиталом могут постепенно ослабить свое действие и в конечном счете могут быть отменены. Модель развития предприятий с иностранным капиталом не является неизменной, в прошлом китайско-иностранные совместно управляемые предприятия играли большую роль в экономике Китая, но из-за ограничений в области учреждения и контроля предприятий основной тенденцией стала замена совместно управляемых предприятий предприятиями с совместным капиталом. В то время Китай еще не входил в ВТО и в отношении совместно управляемых предприятий и предприятий с совместным капиталом действовали льготные меры, поэтому иностранные инвесторы использовали именно такие типы предприятий. Также это способствовало тому, что предприятия со 100\%-м иностранным капиталом играли в этот промежуток времени лишь второстепенную роль. После вступления Китая в ВТО многочисленные льготные меры в отношении предприятий с иностранным капиталом были отменены, а внутренний рынок сбыта был открыт. Иностранным инвесторам уже не требовалось под видом совместно управляемых предприятий и предприятий с совместным капиталом входить на рынок Китая, так постепенно проявлялись преимущества предприятий со 100\%-м иностранным капиталом. Предприятия с иностранным капиталом стали заменять предприятия с совместным капиталом, и это стало главной тенденцией. Предприятия с иностранным капиталом больше опирались на Корпоративное право, поэтому КНР в будущем собирается издать единственный и единый Закон «Об иностранных инвестициях», так как иностранные инвесторы согласно Корпоративному праву могут выбирать только между обществом с ограниченной ответственностью или акционерным обществом с ограниченной ответственностью. Законы «О паевых совместных предприятиях китайского и иностранного капитала», «О китайско-иностранных совместно управляемых предприятиях», «О предприятиях со 100\% иностранным капиталом» в будущем собираются отменить ${ }^{15}$.

Россия в 1999 г. приняла к исполнению единый закон об иностранных инвестициях «Об иностранных инвестициях Российской Федерации», тем самым систематизировала постановления в отношении занятия коммерческой деятельностью, осуществляемой иностранными инвесторами на территории Российской Федерации, а также эффективно гарантировала права и законные интересы иностранных и российских инвесторов. Кроме того, Россия также издала и другие законы, касающиеся иностранных инвестиций, например: «Об инвестициях в основные фонды», «О защите прав и законных интересов инвесторов на рынке ценных бумаг», «Об аренде» и др. Все они предоставили инвесторам более хорошие условия и защитили права и законные интересы иностранных инвесторов.

В первую очередь нужно создать благоприятный инвестиционный климат, не зацикливаясь на предоставлении льготной налоговой политики. Следующие 5-10 лет станут для Китая важным переходным периодом со времен осуществления политики реформ и открытости. В течение долгого времени в будущем экономика Китая будет сталкиваться с довольно серьезными проблемами. Предположительно, в следующие 3-5 лет темп экономического роста Китая снизится примерно на $7 \%$, а масштаб снижения достигнет $30 \%{ }^{16}$. В следующие несколько лет в области методов увеличения прибыли предприятий произойдут значительные изменения. Что касается иностранных инвесторов, то инвестиционный климат является для них очень важным фактором, который включает в себя создание целостной правовой системы, эффективные гарантии со стороны правительства, уменьшение административных барьеров, социальные услуги и др.

\section{Библиография}

1. Ван Баошу. Направления рефрормы структуры Корпоративного права // Китайское правоведение. - 2012. - № 1.

2. Е Вэйпин. Значимость создания Антимонопольного законодательства // Китайское правоведение. - 2012. - №

15 Юй Цзиньсун. Джан Сяонин. Указ. соч. С.180-183.

16 Лю Шицзинь. Китайская экономика стоит перед лицом трёх больших вызовов // Экономика. 2010. № 12. C. 3. 
3. Е Линь. Закон о предприятиях с иностранным капиталом в стадии преобразования // Научная газета университета Янчжоу (Издание научного гуманитарного общества). - 2012. - № 3.

4. Китайский статистический ежегодник 2012. Министерство торговли КНР // http://www. mofcom.gov.cn/.

5. Лю Шицзинь. Китайская экономика стоит перед лицом трех больших вызовов // Экономика. - 2010. - № 12.

6. Пань Чжичэн. Анализ причин отклонения Министерством торговли предложения компании Coca-Cola в покупке компании «Соки Хуэй Юань» // Правоведение. - 2009. - № 7.

7. Пресс-конференция Министерства торговли // http://www.mofcom.gov.cn/article/ae/ ag/201305/20130500137422.shtml.

8. Сесиль Корс Линделл. Объединение законов КНР вызывает беспокойство. Сделка 28 ноября 2007 г. // http://www.law.com/jsp/law/ international/LawArticlelntl.jsp?id=900005558744.

9. Чжан Найгэнь. Обсуждение изменений китайской правовой системы под воздействием правовых положений ВТО // Юрист. - 2011. - № 1.

10. Чэнь Ехун, Чжоу Етин. Размышления на тему ведущей идеологии законодательства по регулированию инвестиционной деятельности в КНР // Право. - 2013. - № 3.

11. Юй Цзиньсун. Джан Сяонин. Разрешение спора между иностранными инвесторами и принимающим государством, а также его влияния // Китайское правоведение. - 2005. № 5.

\section{References}

1. Van Baoshu. Napravleniya reformy struktury Korporativnogo prava // Kitaiskoe pravovedenie. 2012. - № 1 .

2. E Veipin. Znachimost' sozdaniya Antimonopol'nogo zakonodatel'stva // Kitaiskoe pravovedenie. 2012. - №

3. E Lin'. Zakon o predpriyatiyakh s inostrannym kapitalom v stadii preobrazovaniya // Nauchnaya gazeta universiteta Yanchzhou (Izdanie nauchnogo gumanitarnogo obshchestva). - 2012. - № 3.

4. Kitaiskii statisticheskii ezhegodnik 2012. Ministerstvo torgovli KNR // http://www.mofcom.gov.cn/.

5. Lyu Shitszin'. Kitaiskaya ekonomika stoit pered litsom trekh bol'shikh vyzovov // Ekonomika. 2010. - № 12.

6. Pan' Chzhichen. Analiz prichin otkloneniya Ministerstvom torgovli predlozheniya kompanii CocaCola v pokupke kompanii «Soki Khuei Yuan'» // Pravovedenie. - 2009. - № 7.

7. Press-konferentsiya Ministerstva torgovli // http://www.mofcom.gov.cn/article/ae/ ag/201305/20130500137422.shtml.

8. Sesil' Kors Lindell. Ob"edinenie zakonov KNR vyzyvaet bespokoistvo. Sdelka 28 noyabrya 2007 g. // http://www.law.com/jsp/law/ international/LawArticlelntl.jsp?id=900005558744.

9. Chzhan Naigen'. Obsuzhdenie izmenenii kitaiskoi pravovoi sistemy pod vozdeistviem pravovykh polozhenii VTO // Yurist. - 2011. - № 1 .

10. Chen' Ekhun, Chzhou Etin. Razmyshleniya na temu vedushchei ideologii zakonodatel'stva po regulirovaniyu investitsionnoi deyatel'nosti v KNR // Pravo. - 2013. - № 3.

11. Yui Tszin'sun. Dzhan Syaonin. Razreshenie spora mezhdu inostrannymi investorami i prinimayushchim gosudarstvom, a takzhe ego vliyaniya // Kitaiskoe pravovedenie. - 2005. - № 5. 